\title{
Clinical impact of PAI 1 4G/5G gene polymorphism in colorectal carcinoma patients
}

\author{
J. HALAMKOVA ${ }^{1,8}$, I. KISS ${ }^{1, *}$, Z. PAVLOVSKY ${ }^{2}$, J. TOMASEK ${ }^{1}$, J. JARKOVSKY ${ }^{3}$, Z. CECH ${ }^{4}$, D. BEDNAROVA ${ }^{5}$, S. TUCEK ${ }^{1}$, L. HANAKOVA ${ }^{6}$,

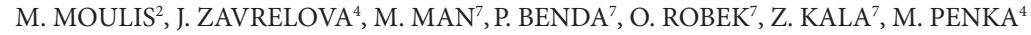

${ }^{1}$ Department of Complex Oncology Care, Masaryk Memorial Cancer Institute, Faculty of Medicine Masaryk University Brno, Zluty kopec 7 , 65653 Brno, Czech Republic; ${ }^{2}$ Institute of Pathology, University Hospital Brno and Faculty of Medicine Masaryk University Brno, Jihlavska 20, 62500 Brno, Czech Republic; ${ }^{3}$ Institute of Biostatistics and Analyses at the Faculty of Medicine and the Faculty of Science of the Masaryk University Brno, Kamenice 126/3, 62500 Brno, Czech Republic; ${ }^{4}$ Department of Haematology, University Hospital Brno and Faculty of Medicine Masaryk University Brno, Czech Republic; ${ }^{5}$ GeneProof a.s., Vinicni 235, 61500 Brno, Czech Republic; ${ }^{6}$ Department of Internal Medicine and Haematooncology, University Hospital Brno and Faculty of Medicine Masaryk University Brno, Czech Republic; ${ }^{7}$ Department of Surgery, University Hospital Brno and Faculty of Medicine Masaryk University Brno, Czech Republic; ${ }^{8}$ Department of Medical Ethics, Faculty of Medicine Masaryk University Brno, Kamenice 5, 62500 Brno, Czech Republic

*Correspondence: kiss@mou.cz

Received June 22, 2012/ Accepted September 17, 2012

\begin{abstract}
Plasminogen activator ihnibitor (PAI 1) belongs to the plasminogen activator system, which is part of the metastatic cascade and significantly contributes to invasive growth and angiogenesis of malignant tumors. Its plasma level is normally low but $4 \mathrm{G} / 4 \mathrm{G}$ homozygotes have higher concentrations of PAI 1 . This genotype may be associated with worse prognosis and proximal location of colorectal cancer than $5 \mathrm{G} / 5 \mathrm{G}$ homozygotes. In our prospective evaluation we examined plasma level PAI 1 (using photometric microplate method ELISA) pre-surgery and, subsequently, 6-8 weeks later, from 80 patients. For the PAI 1 rs1799889 -675 4G/5G polymorphism test the PCR amplification was used.

Analysis of collected data was confirmed that significantly higher plasma levels of PAI 1 were found in patients before starting therapy, which decreased $(\mathrm{p}=0.004)$ after initiation of treatment. Patients with higher plasma level PAI 1 before $(\mathrm{p}=0.013)$ and after therapy $(\mathrm{p}=0.004)$ had significantly shorter survival. We found no relationship between polymorphisms of PAI $1(-6754 \mathrm{G} / 5 \mathrm{G})$ in relation to stage, survival or tumor location. PAI 1 is useful as a negative marker of prognosis and could be advantageous when planning adjuvant treatment of patients with colorectal carcinoma. Although opinions on the importance of polymorphisms of PAI 1 in relation to the prognosis are not uniform, it does seem that their role in the prognosis of patients with colorectal cancer is not essential.
\end{abstract}

Key words: plasminogen activator system, gastrointestinal cancer, plasminogen activator inhibitor 1, -675 4G/5G gene polymorphism

Fibrinolysis is a process, which leads to the degradation of fibrin to fibrin monomers and helps to regulate hemostasis and prevents the creation of an inappropriately large thrombus, which could reduce blood flow in the bloodstream. The main enzyme involved in fibrinolysis is plasmin, which is produced by the liver in inactive form as plasminogen, its half-life is about 2 days, but depending on the activation of the fibrinolytic system, may be significantly shorter [1]. Tissue plasminogen activator (tPA) and urokinase (uPA) are agents converting plasminogen into active plasmin. Tissue plasminogen activator (tPA) together with its receptor (uPAR), tissue activator (tPA, which is synthesized from proenzymes pro-tPA or sc-tPA) and urokinase inhibitors (PAI 1, PAI 2, and PAI 3 - which is identical to the protein $\mathrm{C}$ inhibitor and protease nexin) [1] forms the plasminogen activator system (PAS), which is part of the metastatic cascade and significantly contributes to invasive growth and angiogenesis of malignant tumors [2]. PAI 1 and PAI 2, both belonging to the serpin family (serine protease inhibitor super-family), are its most important specific inhibitors [3].

PAI 1 is a single-chained glycoprotein consisting of 379 amino acids and is predominantly found in vascular smooth 
muscle, in megakaryocytes, endothelium, granulocytes, monocytes, macrophages and tumor cells. It is a serpin, present in plasma and $\alpha$-granules of platelets and has the ability to bind to vitronectin [4-6]. Complex vitronectin PAI 1 has a longer elimination half-life and inhibits the migration of smooth muscle tissue cells by blocking the bond of $\alpha_{v} \beta_{3}$ integrin to vitronectin $[7,8]$. Apart from $\alpha_{v} \beta_{3}$ integrin, it also binds to other groups of integrins, including $\alpha_{v} \beta_{1}, \alpha_{v} \beta_{5}, \alpha \operatorname{IIb} \beta_{3}$ and $\alpha_{8} \beta_{1}$ [9]. The interaction of plasminogen activator inhibitor 1 with the uPA/uPAR complex leads to internalization of the triplet, which stimulates cell proliferation [10]. PAI 1 is the most effective inhibitor of UPA and tPA. The binding of PAI 1 to the uPA/uPAR complex leads to internalization of the complex through endocytic receptors low density lipoprotein (LDL) receptor family as a protein related to the LDL receptor (LDL receptor related protein - LRP). The binding of UPA to PAI 1 interrupts the normal PAI 1-vitronectin interaction and initiates conformational changes in plasminogen activator inhibitor 1, which allows the exposure of a hidden high affinity binding place on LRP [11]. PAI 1 plasma levels are normally low and high plasma levels are associated with various diseases, e.g. vascular diseases $[8,9]$ or malignant tumors.

An increased expression of plasminogen activator inhibitor 1 was found on malignant cells. PAI 1-positive malignant cells have been identified mainly in central parts of tumors, peripheries showed high expression of uPA together with signs of tissue destruction; this supports the theory that an inhibitor could protect tissue from the effects of uPA [3]. It has been shown that PAI 1 inhibits uPA-dependent invasiveness of the lung carcinoma, ovarian carcinoma, choriocarcinoma and fibrosarcoma cell lines [12-14]. Paradoxically, however, increasing PAI 1 expression in tumor tissue of oncology patients is associated with poorer prognosis. Therefore, its role in the entire process of tumor growth remains, for the time being, unclear $[15,16]$ and it is not known why the increasing level of proteolytic inhibitor should be associated with poorer prognosis. Nevertheless, studies with PAI 1-deficient transgenic mice showed that local invasion and tumor-associated angiogenesis are dependent on PAI 1 presence [17]. Therefore, what is PAI l's involvement in tumor progression? The explanation could be as follows: UPAR induction results in a modification of integrin-mediated cell adhesion as the result of interaction with vitronectin. The binding of uPA to uPAR brings about increased affinity to vitronectin. It is, therefore, likely that a PAI 1 increase decreases cell adhesion to the extracellular matrix caused by interference with vitronectin-bound UPAR. This, consequently, facilitates cell invasion, migration, apoptosis and angiogenesis [8, 18-22].

PAI 1 is a glycoprotein whose gene is located on chromosome 7. Up to date at least 28 non-synonymous coding from totally 334 variants has been published [23]. The most commonly studied is a single nucleotide insertion/deletion of guanosine at position $-675.4 \mathrm{G} / 4 \mathrm{G}$ genotype leads to increased gene transcription and thereby increases the plasminogen activator inhibitor 1 protein in plasma. A higher plasmatic level of plasminogen activator inhibitor 1 is associated with reduced fibrinolytic activity. 4G/4G homozygotes have higher concentrations of PAI 1 than 5G/5G homozygotes. The level of PAI 1 in plasma of $4 \mathrm{G} / 5 \mathrm{G}$ heterozygotes is intermediate. The presence of $4 \mathrm{G} / 4 \mathrm{G}$ genotype in the promoter of the PAI 1 gene increases the risk of thrombosis. This polymorphism is also often associated with other diseases such as heart attack [24] or diabetes mellitus [25], and with other types of cancers such as endometrial cancer or breast cancer $[26,27]$. The distribution of each variant is different in different populations, the 4G/4G genotype is more common among Asians (59\%) [28] and Caucasian populations (51\%) [29], Spaniards (47\%) [30] and Indians (54\%) [31], than for Mexicans (34\%) [32] and African-Americans (24\%) [33].

In patients with breast cancer and $4 \mathrm{G} / 4 \mathrm{G}$ genotype, a greater probability of the involvement of lymph nodes has been shown, thus making prognosis worse [27]. Some published studies also suggest that the $4 \mathrm{G} / 4 \mathrm{G}$ genotype may be associated with advanced colorectal cancer and 5G/5G genotype with less advanced tumors [34], while the $4 \mathrm{G} / 4 \mathrm{G}$ genotype may be associated with proximal cancer of the colon [35].

There were also published articles, according to which the other polymorphism 1334G/A should be associated with a higher incidence of colorectal cancer, so far it has been tested only a small group of patients and these findings should be corroborated by others studies [36]. Generally, however, it were published a very few papers focused on the topic of colorectal cancer.

\section{Patients and methods}

Patients. Prospective evaluation involved a total of $80 \mathrm{pa}-$ tients treated for adenocarcinoma of the colon or rectum at the Department of Clinical Oncology, University Hospital Brno, comprising of 55 men and 25 women, aged $39-80$ years with a median of 62.5 years. The group consisted of $25(31.3 \%)$ patients of TNM classification stage I, 19 (23.8\%) stage II, 17 (21.3\%) stage III patients and 19 (23.8\%) stage IV patients. Sixteen patients died during the evaluation period, the death of 3 patients were not associated with the primary disease, 13 patients died due to the progression or relapse of the colorectal cancer. Of the total of 80 patients, there were 22 (27.5\%) with cancer of colon descendens and $14(17.5 \%)$ patients suffered from carcinoma of the colon ascendens, and 44 patients (55\%) were diagnosed with adenocarcinoma of the rectum.

To simplify categorization, transverse carcinomas were evaluated according to their direct location: if the tumor was in the splenic flexure, it was assigned to the group of descending colon cancer, along with tumors of the sigmoid colon. If the tumor was located in the hepatic flexure, then it was placed in the group of ascending colon cancer. The main patient characteristics are summarized in Table 1.

For the project the tumor tissue of patients was used after resection for colorectal cancer (primary tumor or metastases) conducted in the Surgical Clinic of the University Hospital 
Brno. Patients were included in the project after giving their informed consent. Participation in the study was represented only by a sampling of tumor tissue, which was not carried beyond the standard treatment and diagnostic procedures and collection of peripheral blood at the same time, also as part of standard tests. Patients, in addition to the above characteristics (plasminogen activator inhibitor 1 in peripheral blood before treatment and 6-8 weeks after initiation of therapy \{for stages I and II after surgery, for stage III after the initiation adjuvant chemotherapy, for stage IV after start of palliative chemotherapy\}, rs1799889-675 4G/5G gene polymorphism of PAI 1) were assessed for age, gender, type, grade, TNM classification, Dukes classification, response to treatment (by RECIST criteria [37]), overall survival.

As the adjuvant chemotherapy, the protocol based on FUFA (5-Fluorouracil/Leucovorin) was administered. In the scope of palliative treatment only the effect the first line chemotherapy based on irinotecan or oxaliplatin, possibly in combination with bevacizumab was evaluated. During the monitoring 2 patients were treated with acetyl salicylic acid and 1 patient with low molecular weight heparin, no patient was treated with warfarin or other oral anticoagulation therapy.

Material sampling and processing. Peripheral blood for plasma PAI 1 analysis was sampled pre-surgery or, in TNM stage IV patients, before the initiation of chemotherapy and, subsequently, 6-8 weeks later. The evaluation of functional activity of PAI 1 was performed using the photometric microplate method on the ELISA reader Expert Plus (ASYS Hitech) with Spectrolyse/(pLPAI-1) set by Biopool (A Trinity Biotech Company). Plasma samples were prepared from blood samples collected into 1:10 diluted $0.109 \mathrm{M}$ sodium citrate and centrifuged for 15 minutes at $2500 \mathrm{~g}$ in a cooled centrifuge $\left(15^{\circ} \mathrm{C}\right)$ and stored at $-70^{\circ} \mathrm{C}$. The reference range of $0-10.0 \mathrm{AU} / \mathrm{ml}$ was used to assess PAI 1 plasma levels.

For the determination of gene polymorphisms of plasminogen activator inhibitor 1 rs1799889 -675 4G/5G a DNA sample from peripheral blood sample was isolated using a commercially available isolation kit (QIA Blood Mini Kit, Qiagen), allowing rapid isolation of DNA from small quantities of peripheral blood $(200 \mu \mathrm{l})$ collected into collection tubes with K3 EDTA. For the 4G/5G polymorphism test the PCR amplification method was used followed by the cleavage product, using primers 5 'CAC AGA GAG AGT CTG GCC ACG T-3' and 5 'CCA ACA GAG GAC TCT TGG TCT 3' (East-Port Prague, Ltd., UK) and restriction enzyme BSL I (Biotech, R0555S). PCR was carried out in a thermal cycler (Mastercycler gradient, Eppendorf), each sample contained $0.5 \mu \mathrm{g}$ genomic DNA, $15 \mathrm{pmol}$ of each primer, dNTP $100 \mu \mathrm{mol}$ (Promega U1240, U.S.), 5 Green GoTaq buffer and 1U GoTaq polymerase (Promega M3171, U.S.)

PCR was carried out in 35 cycles at temperatures of $95^{\circ} \mathrm{C}$ for $20 \mathrm{~s}, 60^{\circ} \mathrm{C}$ for $25 \mathrm{~s}$ and $20 \mathrm{~s}$ at $72^{\circ} \mathrm{C}$. Subsequently, amplicons were incubated with a volume of $20 \mu \mathrm{l}$ for at least 3 hours at $55^{\circ} \mathrm{C}$ with $1 \mathrm{U}$ of restriction enzyme BSL I (R0555S Biotech). PCR fragments were electrophoretically separated on $4.5 \%$
Table 1. Description of patients

\begin{tabular}{lc}
\hline Age (mean, median (min - max)) & $62.5,62.5(39.0-80.0)$ \\
Men - N (\%) & $55(68.8)$ \\
\hline Follow-up median (min - max) - months & $18.5(3.0-42.0)$ \\
\hline Stage (TNM classification) & $\mathbf{N}(\%)$ \\
$\mathbf{1}$ & $25(31.3)$ \\
$\mathbf{2}$ & $19(23.8)$ \\
$\mathbf{3}$ & $17(21.3)$ \\
$\mathbf{4}$ & $19(23.8)$ \\
\hline Stage (Dukes classification) & $\mathbf{N}(\%)$ \\
$\mathbf{A}$ & $25(31.3)$ \\
$\mathbf{B}$ & $19(23.8)$ \\
$\mathbf{C}$ & $17(21.3)$ \\
\hline Grade & $\mathbf{N}(\%)$ \\
$\mathbf{1}$ & $25(31.3)$ \\
$\mathbf{2}$ & $39(48.8)$ \\
$\mathbf{3}$ & $14(17.5)$ \\
$\mathbf{4}$ & $1(1.3)$ \\
unknown & $1(1.3)$ \\
\hline Gene polymorphism PAI 1 rs1799889-675 4G/5G & $\mathbf{N}(\%)$ \\
$4 \mathrm{G} / 4 \mathrm{G}$ & $26(32,5)$ \\
$4 \mathrm{G} / 5 \mathrm{G}$ & $32(40,0)$ \\
5G/5G & $22(27,5)$ \\
\hline
\end{tabular}

agarose gel (LE Agarose, Promega) containing ethidium bromide and visualized under UV light (Transilluminator, Vilber Lourmat TFX 20M). Each sample was classified into one of the three variants of possible genotypes $4 \mathrm{G} / 4 \mathrm{G}, 4 \mathrm{G} / 5 \mathrm{G}$ or $5 \mathrm{G} / 5 \mathrm{G}$.

Clinical evaluation. All patients were monitored as part of their routine follow-up; patients in complete remission were, after the post-surgery sampling, evaluated at 3-monthly intervals using imaging methods. Chemotherapy patients were evaluated at monthly intervals, using imaging methods every 3 months. Suspicion of progressive disease was verified by $\mathrm{CT}$ abdomen/thorax or chest X-ray. Treatment response was assessed according to RECIST criteria [37].

Ethical aspects. The study patients were enrolled after signing an informed consent form that was approved by the Ethical Committee of the University Hospital Brno.

Statistical analysis. Descriptive statistics (N, median, minimum and maximum, 5 and $95 \%$ percentile) were calculated for continuous variables and absolute and relative numbers of patients in each category for categorical variables. Contingency tables were tested with a Chi-square test and Fisher's exact test. A Paired t-test was employed to assess the difference between PAI 1 before and after treatment. The relationship between continuous variables was calculated using Spearman's Nonparametric Correlation. The association between categorical variables and survival was projected into the Kaplan-Meier survival curve and tested with the log-rank test. A P value of less than 0.05 was considered as statistically significant. The analysis was performed with the support of Statistica for Windows 8 and SPSS 17. 


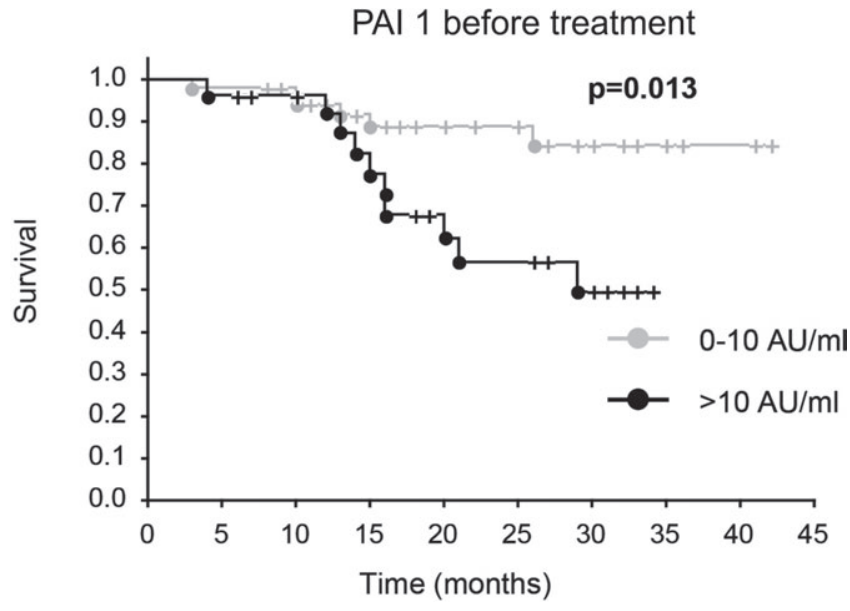

Fig. 1. Correlation between plasma level PAI 1 before therapy and survival

\section{Results}

Tab. 2 shows that plasma PAI 1 levels decreased significantly after the operation or start of treatment. This difference in plasma PAI 1 levels before and after operation or treatment initiation was statistically significant $(\mathrm{p}=0.004)$. It follows that the plasma levels of PAI 1 is affected by the surgery and initiation of treatment and after several weeks decreases. This could

Table 2. Relationship of plasma levels of PAI 1 before and after initiation of therapy

\begin{tabular}{lccc}
\hline & \multicolumn{2}{c}{ PAI 1 (AU/ml) } & \multirow{2}{*}{$\begin{array}{c}\text { Difference of } \\
\text { PAI 1 }\end{array}$} \\
\cline { 2 - 3 } & before therapy & after therapy & 80 \\
\hline $\mathbf{N}$ & 80 & 80 & -2.8 \\
\hline Median & 6.7 & 3.5 & $-31.4-25.4$ \\
\hline Min - max & $0.0-42.2$ & $0.0-33.0$ & $-15.8-15.6$ \\
\hline Percentil 5 - 95\% & $0.0-31.1$ & $0.0-23.8$ & $\mathbf{0 . 0 0 4}$ \\
\hline $\mathbf{p}^{1}$ & & & \\
\hline${ }^{1}$ Tested with paired t-test.
\end{tabular}

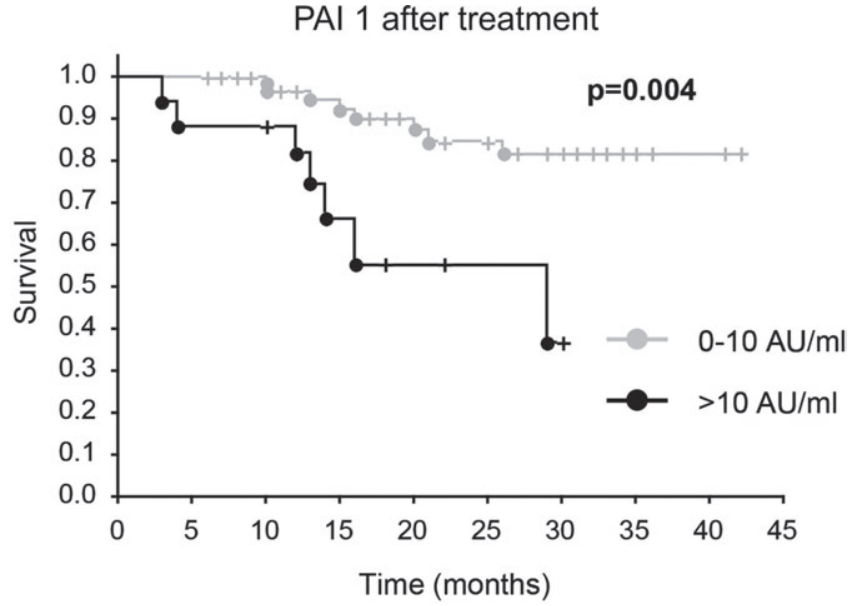

Fig. 2. Correlation between plasma level PAI 1 after initiation of therapy and survival

mean, that PAI 1 occurs in the organism in close association with the malignant process, and after its removal the level of PAI 1 in peripheral blood decreases.

Fig. 1 and fig. 2 also suggest that there is a statistically significant association between soluble PAI 1 levels and survival, i.e. that survival is significantly lower in patients with pathological plasma PAI 1 levels than in patients with plasma levels within the reference range. Statistically, survival was significantly shorter in patients with pathological PAI 1 plasma levels measured before the initiation of treatment as well as 6-8 weeks later [38].

Another part of our study was to evaluate the impact of genetic polymorphisms of plasminogen activator inhibitor 1 in relation to the stage of disease. Thus, as suggested by some authors, the $4 \mathrm{G} / 4 \mathrm{G}$ genotype should be associated with more advanced colorectal cancers and 5G/5G genotype with less advanced colorectal cancer tumors. In our analysis, we did not find any statistical evidence to confirm these findings (Table 3).

We analyzed also whether individual polymorphisms may be associated with specific tumor location in the colon and rectum. The $4 \mathrm{G} / 4 \mathrm{G}$ genotype should be, according to some publications, associated with proximal colon cancers [35].

Table 3. Relationship between gene polymorphism PAI 1 -675 4G/5G and stage of disease

\begin{tabular}{|c|c|c|c|c|c|}
\hline & \multicolumn{4}{|c|}{ Stage } & \multirow{2}{*}{$\mathbf{p}^{1}$} \\
\hline & I & II & III & IV & \\
\hline 4G/4G genotype $\mathrm{N}(\%)$ & $8(32.0)$ & $3(15.8)$ & $7(41.2)$ & $8(42.1)$ & 0.321 \\
\hline 4G/5G genotype N (\%) & $10(40.0)$ & $7(36.8)$ & $7(41.2)$ & $8(42.1)$ & \\
\hline 5G/5G genotype $N(\%)$ & $7(28.0)$ & $9(47.4)$ & $3(17.6)$ & $3(15.8)$ & \\
\hline $\mathbf{p}^{1}$ (group vs. others) & 0.997 & 0.057 & 0.516 & 0.350 & \\
\hline
\end{tabular}

${ }^{1}$ Tested with maximum likelihood Chi-square test (more than two categories) or Fisher's exact test (two categories) 
Even in this case we have not found a statistically significant relationship (Table 4).

As shown in fig. 3. we did not find a relationship between the gene polymorphisms of PAI 1 and patient survival (4G/4G $\mathrm{p}=0.718 ; 4 \mathrm{G} / 5 \mathrm{G} \mathrm{p}=0.928 ; 5 \mathrm{G} / 5 \mathrm{G} \mathrm{p}=0.633$ ).

\section{Discussion}

A number of studies explored in depth the importance of the individual plasminogen activator system elements for oncology patients' survival. An increased uPA, uPAR, PAI 1 and PAI 2 expression in tumor tissue was confirmed in a number of tumors, such as breast, ovarian, kidney and stomach [39-47] and it is certain that these factors play an important role in tumor invasiveness and metastasizing. Low PAI 1 expression in tumor tissue in early stages of the disease is in accordance with the theory that, by releasing tumor cells from the matrix, PAI 1 facilitates the invasion of tumors $[48,18]$.

uPA as well as PAI 1 expression in other tumors, e.g. in breast cancer, was perceived as an independent prognostic factor for shorter survival [49]. Knoop et al. demonstrated that, in these patients, PAI 1 itself is a predictor of distant rather than local relapse. This verifies the important role of PAS in the metastasizing of malignant tumors [50]. Even though Ito et al. [51] states that PAI 1-negative malignant stomach tumors show higher incidence of liver metastases and thus poorer prognosis.

At the beginning of the study we assumed the correlation between plasma levels of PAI 1 before treatment and its decrease 6-8 weeks after the start of therapy (after surgery or initiation of chemotherapy with or without radiotherapy). We have shown a statistically significant reduction in plasmatic PAI 1 levels after surgery or treatment initiation. This suggests a possible link between soluble PAI 1 levels and tumor viability and could serve as a marker of surgical procedure curativeness or, alternatively, tumor treatment effectiveness [52]. Our model of patients' survival associated with soluble PAI 1 levels, on a Kaplan-Meier curve, in line with the literature [53], showed statistically significantly lower survival of patients with pathological levels of soluble PAI 1 prior to treatment, even when PAI 1 values did not decline to the reference range after treatment initiation [38].

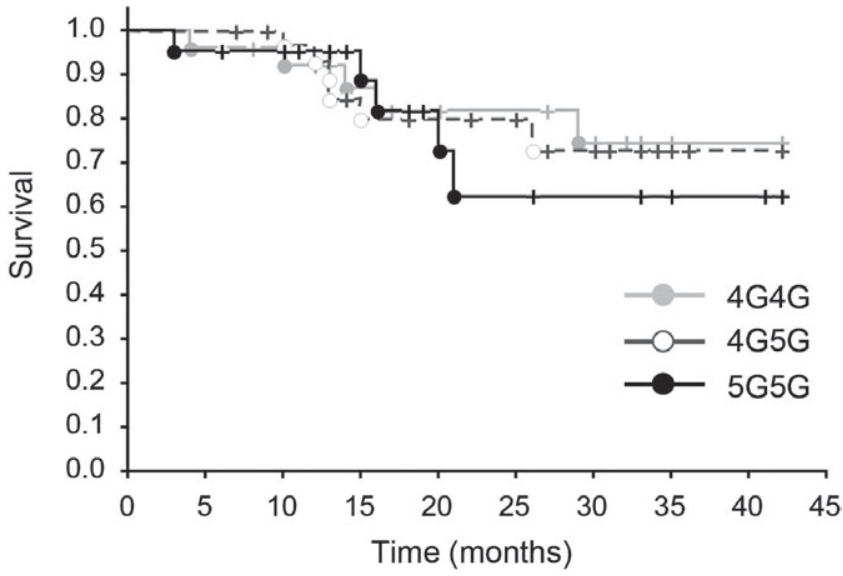

Fig. 3. Relationship between gene polymorphism 4G/4G PAI 1 and survival

In their group of patients Herszényi et al. demonstrated a relationship between patient survival and plasmatic PAI 1 levels as well as the importance of plasmatic PAI 1 in invasively growing colorectal carcinomas and the progression of colorectal non-cancerogenic lesions into carcinomas [54]. But in our study we show that a decrease of plasmatic PAI 1 level after surgery or treatment initiation is very important for prognosis.

In the other part of our analysis, we focused on the research of - 675 4G/5G (rs1799889) polymorphisms of PAI 1 for patients with colorectal carcinoma. Castelló et al. and Zhang et al. in their group of patients showed a greater likelihood of lymph node involvement in patients with breast cancer with the $4 \mathrm{G} / 4 \mathrm{G}$ genotype, and thus worse prognosis $[27,55]$. Lei et al. on the contrary, in his research showed a worse prognosis in patients with $5 \mathrm{G} / 5 \mathrm{G}$ genotype [56]. Neither of these hypotheses were confirmed by Blasiak et al. in his study [57]. The results of the current research can be regarded as ambiguous. This type of polymorphism has been studied in the context of tumor aggressiveness in patients with prostate cancer, where its relationship to prognosis was also not confirmed [58]. And results of study of Vossen et al. did not support an effect of PAI 1 4G/5G on colorectal cancer risk [59]. Palmirotta et al.

Table 4. Relationship between gene polymorphism PAI 1 -675 4G/5G and tumor location (Due to discrepancies in the source documents, 3 patients were not included in this analysis).

\begin{tabular}{lccc}
\hline & \multicolumn{3}{c}{ Tumor location } \\
\cline { 2 - 4 } & colon ascendens & colon descendens & rectum \\
\hline 4G/4G genotype N (\%) & $4(28.6)$ & $7(35.0)$ & $12(27.9)$ \\
4G/5G genotype N (\%) & $5(35.7)$ & $8(40.0)$ & $19(44.2)$ \\
5G/5G genotype N (\%) & $5(35.7)$ & $5(25.0)$ & $12(27.9)$ \\
$\mathbf{p}^{1}$ (group vs. others) & 0.801 & 0.831 & 0.859 \\
\hline
\end{tabular}

${ }^{1}$ Tested with maximum likelihood Chi-square test (more than two categories) or Fisher's exact test (two categories) 
in their research concluded that plasma PAI 1 levels in breast cancer patients could represent a useful prognostic variable for relapse, although PAI 1 polymorphism might not represent a genetic susceptibility factor [60]. Tee et al. showed no significant association between cervical neoplasia cases and gene polymorphisms of uPA, uPAR and PAI 1 . However, they found a mutual interaction between uPA/PAI 1 genes, which women carrying the uPA/PAI 1 CC/4G4G allele had a 1.70-fold higher risk of cervical neoplasia compared with those carrying the CC/4G5G allele. Individuals with uPA/PAI 1 CC/4G5G allele were in high susceptibility for cervical neoplasia. The combined polymorphism of uPA/PAI 1 might diminish the ability of PAI 1 to inhibiting cervical cancer carcinogenesis when PAI 1 alone as the role of inhibitor [61]. Contrary to this study Su et al. and Gilabert-Estellés et al. published that patients with $4 \mathrm{G} / 4 \mathrm{G}$ genotype were at significantly higher risk of endometrial cancer $[62,63]$.

For colorectal cancer Försti et al. in their work demonstrates that the $4 \mathrm{G} / 4 \mathrm{G}$ genotype is associated with shorter survival because it is linked more to Dukes $\mathrm{C}$ tumors, in contrast to the $5 \mathrm{G} / 5 \mathrm{G}$ genotype, which is associated more with tumors stage A and B [34]. But in our group of patients we have not seen in either of the examined polymorphisms a significant relation to survival. In relation to the stages, the distribution of polymorphisms was entirely homogeneous and hence in this case a statistically significant difference wasn't proven. These results are consistent with other studies, Smolarz et al., in which the relationship of PAI $14 \mathrm{G} / 5 \mathrm{G}$ polymorphism to the prognosis of patients with colorectal cancer, was not confirmed [64]. Nor did we prove the association of these polymorphisms to localization of colorectal cancer, as suggested by Loktionov et al. in his article (4G/4G genotype should be associated with proximal colon cancers) [35]. This is so far the only published work focused on monitoring the $4 \mathrm{G} / 5 \mathrm{G}$ polymorphism in relation to the localization of colorectal carcinoma.

We have shown a statistically significant reduction in plasmatic PAI 1 levels after surgery or treatment initiation. Our model of patients' survival associated with soluble PAI 1 levels, on a Kaplan-Meier curve showed statistically significantly lower survival of patients with pathological levels of soluble PAI 1 prior to treatment, even when PAI 1 values did not decline to the reference range after treatment initiation. Plasma PAI 1 could be advantageous when planning adjuvant treatment of patients with colorectal carcinoma. Although opinions on the importance of polymorphisms of PAI 1 in relation to the prognosis of cancer are not uniform, it does seem, and our results confirm, that their role in the prognosis of patients with colorectal cancer is not essential but it must be admitted that the analysis based upon a small number of enrolled patients could potentially lead to false-negative results. Whatever the case, this issue deserves further exploration.

Acknowledgements: This study was founded by Institutional Resources for Supporting the Research Organization provided by the Ministry of Health of the Czech Republic in 2012.

\section{References}

[1] BRUMMEL-ZIEDINS K, ORFEO T, SWORDS JENNY N, et al. Blood coagulation and fibrinolysis. In: Greer JP, Foerster J, Rodgers JM, et al.editors. Wintrobe's Clinical Hematology, 12th ed. Baltimore: Lippincott Wiliams \& Wilkins, 2009: 528-619.

[2] SCHMITT M, HARBECK M, THOMSSEN C, WILHELM O, MAGDOLEN V et al. Clinical impact of the plasminogen activation system in tumor invasion and metastasis: Prognostic relevance and target therapy. Thromb Haemost 1997; 78: 285-296.

[3] PYKE C, KRISTENSEN P, RALFKIAER E, ERIKSEN J, DANØ $\mathrm{K}$ et al. The plasminogen activation system in human colon cancer: Messenger RNA for the inhibitor PAI1 is located in endothelial cells in tumor stroma. Cancer Res 1991; 51: 4067-4071.

[4] FAY WP, SHAPIRO AD, SHIH JL, SCHLEEF RR, GINSBURG D et al. Complete deficiency of plasminogen-activator inhibitor type 1 due to a frame-shift mutation. N Engl J Med 1992; 327: 1729-1733. http://dx.doi.org/10.1056/ NEJM199212103272406

[5] CARMELIET P, STASSEN JM, SCHOONJANS L, REAM B, VAN DEN OORD JJ et al. Plasminogen activator inhibitor -1 gene-deficient mice. II. Effect on haemostasis, thrombosis and thrombolysis. J Clin Invest 1993; 92: 2756-2760. http://dx.doi. org/10.1172/JCI116893

[6] HILL SA, SHAUGHNESSY SG, JOSHUA P, RIBAU J, AUSTIN $\mathrm{RC}$ et al. Differential mechanisms targeting type 1 plasminogen activator inhibitor and vitronectin into the storage granules of a human megakaryocytic cell line. Blood 1996; 87: 5061-5073.

[7] STEFANSSON S, PETICLERC E, WONG MK, McMAHON GA, BROOKS PC et al. Inhibition of angiogenesis in vivo by plasminogen activator inhibitor-1. J Biol Chem 2001; 276: 8135-8141. http://dx.doi.org/10.1074/jbc.M007609200

[8] STEFANSSON S, LAWRENCE DA. The serpin PAI-1 inhibits cell migration by blocking integrin alpha $\mathrm{V}$ beta 3 binding to vitronectin. Nature 1996; 383: 441-443. http://dx.doi. org/10.1038/383441a0

[9] SUGIURA Y, MA L, SUN B, SHIMADA H, LAUG WE et al. The plasminogen-plasminogen activator (PA) system in neuroblastoma: role of PA inhibitor-1 in metastasis. Cancer Res 1999; 59: 1327-1336.

[10] NYKJAER A, CONESE M, CHRISTENSEN EI, OLSON D, CREMONA O et al. Recycling of the urokinase receptor upon internalization of the UPA: serpin complexes. EMBO J 1997; 16: 2610-2620. http://dx.doi.org/10.1093/emboj/16.10.2610

[11] CHAZAUD B, RICOUX R, CHRISTOV C, PLONQUET A, GHERARDI RK et al. Promigratory effect of plasminogen activator inhibitor- 1 on invasive breast cancer cell populations. Am J Pathol 2002; 160: 237-246. http://dx.doi.org/10.1016/ $\underline{\text { S0002-9440(10)64367-2 }}$

[12] BRUCKNER A, FILDERMAN AE, KIRCHHEIMER JC, BINDER BR, REMOLD HG. Endogenous receptor-bound urokinase mediates tissue invasion of the human lung carcinoma cell lines A549 and Calu-1. Cancer Res 1992; 52: 3043-3047. 
[13] KOBAYASHI H, MONIVA N, GOTOH J, SUGIMURA M, TERAO $\mathrm{T}$ et al. Role of activated protein $\mathrm{C}$ in faciliting basement membrane invasion by tumor cells. Cancer Res 1994; 54: 261-267.

[14] PRAUS M, COLLEN D, GERARD RD. Both u-PA inhibition and vitronectin binding by plasminogen activator inhibitor 1 regulate HT1080 fibrosarcoma cell metastasis. Int J Cancer 2002; 102: 584-591. http://dx.doi.org/10.1002/ijc.10767

[15] HARBECK N, SCHMITT M, KATES RE, KIECHLE M, ZEMZOUM I et al. Clinical utility of urokinase-type plasminogen activator and plasminogen activator inhibitor-1 determination in primary breast cancer tissue for individualized therapy concepts. Clin Breast Cancer 2002; 3: 196-200. http://dx.doi. org/10.3816/CBC.2002.n.023

[16] TAPONECO F, CURCIO C, GIUNTINI A, NARDINI V, FORNACIARI $\mathrm{G}$ et al. Expression and prognostic significance of urokinase and plasminogen activator inhibitor type- 1 in endometrial hyperplazia and cancer. J Exp Clin Canc Res 2001; 20: 239-246.

[17] BAJOU K, NOËL A, GERARD RD, MASSON V, BRUNNER $\mathrm{N}$ et al. Absence of host plasminogen activator inhibitor 1 prevents cancer invasion and vascularization. Nat Med 1998; 4: 923-928. http://dx.doi.org/10.1038/nm0898-923

[18] DENG C, CURRIDEN SA, WANG S, ROSENBERG S, LOSKUTOFF DJ. Is plasminogen activator inhibitor 1 the molecular switch that governs urokinase receptor-mediated cell adhesion and release? J Cell Biol 1996; 134: 1563-1571. http://dx.doi.org/10.1083/jcb.134.6.1563

[19] KANSE SM, KOST C, WILHELM OG, ANDREASEN PA, PREISSNER KT et al. The urokinase receptor is a major vitronectin-binding protein on endothelial cells. Exp Cell Res 1996; 224: 344-353. http://dx.doi.org/10.1006/ excr.1996.0144

[20] ABE J, URANO T, KONNO H, ERHAN Y, TANAKA T et al. Larger and more invasive colorectal carcinoma contains larger amounts of plasminogen activator inhibitor type 1 and its relative ratio over urokinase receptor correlates well with tumor size. Cancer 1999; 86: 2602-2611. http://dx.doi. org/10.1002/(SICI) 1097-0142(19991215)86:12<2602::AIDCNCR4>3.0.CO;2-S

[21] KWAAN HC, WANG J, SVOBODA K, DECLERCK PJ. Plasminogen activator inhibitor 1 may promote tumour growth through inhibition of apoptosis. Br J Cancer 2000; 82: 1702-1708. http://dx.doi.org/10.1054/bjoc.2000.1207

[22] BALSARA RD, PLOPLIS VA. Plasminogen activator inhibitor-1: the double-edged sword in apoptosis. Thromb Haemost 2008; 100: 1029-1036.

[23] The National Center for Biotechnology Information database,[cited 2012-08-07]. Available:<URL http://www.ncbi. nlm.nih.gov/SNP/snp_ref.cgi?chooseRs=all\&locusId $=5054 \&$ mrna=NM_000602.3\&ctg=NT_007933.15\&prot=NP_00059 3.1\&orien $=$ forward\&refresh $=$ refresh $>$.

[24] ERIKSSON P, KALLIN B, VAN'T HOOFT FM, BAVENHOLM P, HAMSTEN A et al. Allele-specific increase in basal transcription of the plasminogen-activator inhibitor 1 gene is associated with myocardial infarction. P Natl Acad Sci USA; 92: 1851-1855. http://dx.doi.org/10.1073/pnas.92.6.1851
[25] MANSFIELD MW, STICKLAND MH, GRANT PJ. Plasminogen activator inhibitor-1 (PAI-1) promoter polymorphism and coronary artery disease in non-insulin dependent diabetes. Thromb Haemost 1995; 74: 1032-1034.

[26] SU CK, YEH KT, YEH CB, WANG PH, HO ES et al. Genetic polymorphism of the plasminogen activator inhibitor-1 is associated with an increased risk of endometrial cancer. J Surg Oncol 2011; 104: 755-759. http://dx.doi.org/10.1002/ jso. 22035

[27] CASTELLO R, ESPANA F, VAZQUEZ C, FUSTER C, ALMENAR SM et al. Plasminogen activator inhibitor-1 $4 \mathrm{G} / 5 \mathrm{G}$ polymorphism in breast cancer patients and its association with tissue PAI-1 levels and tumor severity. Thromb Res 2006; 117: 487-492. http://dx.doi.org/10.1016/ j.thromres.2005.03.025

[28] WANG AY, POON P, LAI FM, YU L, CHOI PC et al. Plasminogen activator inhibitor-gene polymorphism 4G/4G genotype and lupus nephritis in Chinese patients. Kidney Int 2001; 59: 1520-1528. http://dx.doi.org/10.1046/j.15231755.2001.0590041520.x

[29] MANSFIELD MW, STICKLAND MH, GRANT PJ. PAI-1 concentrations in first-degree relatives of patients with non-insulin-dependent diabetes: metabolic and genetic associations. Thromb Haemost 1997; 77: 357-361.

[30] TASSIES D, ESPINOSA G, MUNOZ-RODRIGUEZ FJ, FREIRE C, CERVERA R et al. The $4 \mathrm{G} / 5 \mathrm{G}$ polymorphism of the type 1 plasminogen activator inhibitor gene and thrombosis in patients with antiphospholipid syndrome. Arthritis Rheum 2000; 43: 2349-2358. http://dx.doi.org/10.1002/15290131(200010)43:10<2349::AID-ANR24>3.0.CO;2-J

[31] PEGORARO RJ, RANJITH N. Plasminogen activator inhibitor type 1 (PAI-1) and platelet glycoprotein IIIa (PGIIIa) polymorphisms in young Asian Indians with acute myocardial infarction. Cardiovasc J South Afr 2005; 16: 266-270.

[32] RUIZ-QUEZADA S, VAZQUEZ-DEL MERCADO M, PARRA-ROJAS I, RANGEL-VILLALOBOS H, BEST-AGUILERA $\mathrm{C}$ et al. Genotype and allele frequency of PAI-1 promoter polymorphism in healthy subjects from the west of Mexico. Association with biochemical and hematological parameters. Ann Genet 2004; 47: 155-162. http://dx.doi.org/10.1016/ j.anngen.2003.12.001

[33] HOOPER WC, LALLY C, AUSTIN H, RENSHAW M, DILLEY A et al. The role of the t-PA I/D and PAI-1 4G/5G polymorphisms in African-American adults with a diagnosis of myocardial infarction or venous thromboembolism. Thromb Res 2000; 99: 223-230. http://dx.doi.org/10.1016/S00493848(00)00236-X

[34] FORSTI A, LEI H, TAVELIN B, ENQUIST K, PALMQVIST R et al. Polymorphisms in the genes of the urokinase plasminogen activation system in relation to colorectal cancer. Ann Oncol 2007; 18: 1990-1994. http://dx.doi.org/10.1093/annonc/mdm 361

[35] LOKTIONOV A, WATSON MA, STEBBINGS WS, SPEAKMAN CT, BINGHAM SA et al. Plasminogen activator inhibitor-1 gene polymorphism and colorectal cancer risk and prognosis. Cancer Lett 2003; 189: 189-196. http://dx.doi. org/10.1016/S0304-3835(02)00556-6 
[36] SMOLARZ B, ROMANOWICZ-MAKOWSKA H, KULIG A. Plasminogen activator inhibitor 1 1334G/A genetic polymorphism in colorectal cancer. Acta Biochim Pol 2003; 50: 489-495.

[37] THERASSE P, ARBUCK SG, EISENHAUER EA, WANDERS J, KAPLAN RS et al. New guidelines to evaluate the response to treatment in solid tumors. JNCI 2000; 92: 205-216. http:// dx.doi.org/10.1093/jnci/92.3.205

[38] HALAMKOVA J, KISS I, PAVLOVSKY Z, JARKOVSKY J, TOMASEK J et al. Clinical Relevance of uPA, uPAR, PAI 1 , PAI 2 Tissue Expression and Plasma PAI 1 Level in Colorectal Carcinoma Patients. Hepatogastroenterology 2011; 58: 1918-1925.

[39] WANG L, MADIGAN MC, CHEN H, LIU F, PATTERSON $\mathrm{KI}$ et al. Expression of urokinase plasminogen activator and its receptor in advanced epithelial ovarian cancer patients. Gynecol Oncol 2009; 114: 265-272. http://dx.doi.org/10.1016/ j.ygyno.2009.04.031

[40] NEKARDA H, SIEWERT JR, SCHMITT M. Tumour-associated proteolytic factors UPA and PAI- 1 and survival in totally resected gastric cancer. Lancet 1994; 343: 117. http://dx.doi. org/10.1016/S0140-6736(94)90845-1

[41] ZEMZOUM I, KATES RE, ROSS JS, DETTMAR P, DUTTA $\mathrm{M}$ et al. Invasion factors $\mathrm{UPA} / \mathrm{PAI}-1$ and HER2 status provide independent and complementary information on patient outcome in node-negative breast cancer. J Clin Oncol 2003; 21: 1022-1028. http://dx.doi.org/10.1200/JCO.2003.04.170

[42] HILDENBRAND R, SCHAAF A, DORN-BEINEKE A, ALLGAYER H, SUTTERLIN $M$ et al. Tumor stroma is the predominant uPA-, uPAR-, PAI-1-expressing tissue in human breast cancer: prognostic impact. Histol Histopathol 2009; 24 869-877.

[43] SAKAKIBARA T, HIBI K, KOIKE M, FUJIWARA M, KODERA Y et al. Plasminogen activator inhibitor-1 as a potential marker for the malignancy of colorectal cancer. Br J Cancer 2005; 93: 799-803. http://dx.doi.org/10.1038/sj.bjc.6602743

[44] OHBA K, MIYATA Y, KANDA S, KOGA S, HAYASHI T et al. Expression of urokinase-type plasminogen activator, urokinase-type plasminogen activator receptor and plasminogen activator inhibitors in patients with renal cell carcinoma: correlation with tumor associated macrophage and prognosis. J Urol 2005; 174: 461-465. http://dx.doi.org/10.1097/01. ju.0000165150.46006.92

[45] PEDERSEN H, GRONDHAL-HANSEN J, FRANCIS D, OSTERLIND K, HANSEN HH et al. Urokinase and plasminogen activator inhibitor type 1 in pulmonary adenocarcinoma. Cancer Res 1994; 54: 120-123.

[46] KONECNY G, UNTCH M, PIHAN A, KIMMIG R, GROPP $\mathrm{M}$ et al. Association of urokinase-type plasminogen activator and its inhibitor with disease progression and prognosis in ovarian cancer. Clin Cancer Res 2001; 7: 1743-1749.

[47] MYTNIK M, STASKO J. D-dimer, plasminogen activator inhibitor-1, prothrombin fragments and protein $\mathrm{C}$ - role in prothrombotic state of colorectal cancer. Neoplasma 2011; 58: 235-238. http://dx.doi.org/10.4149/neo $2011 \quad 03 \quad 235$

[48] WALTZ DA, NATKIN LR, FUJITA RM, WEI Y, CHAPMAN HA. Plasmin and plasminogen activator inhibitor type 1 pro- mote cellular motility by regulating the interaction between the urokinase receptor and vitronectin. J Clin Invest 1997; 100: 58-67. http://dx.doi.org/10.1172/JCI119521

[49] GRONDAHL-HANSEN J, CHRISTENSEN IJ, ROSENQUIST C, BRUNNER N, MOURIDSEN HT et al. High levels of urokinase-type plasminogen activator and its inhibitor PAI-1 in cytosolic extracts of breast carcinomas are associated with poor prognosis. Cancer Res 1993; 53: 2513-2521.

[50] KNOOP A, ANDREASEN PA, ANDERSEN JA, HANSEN S, LAENKHOLM AV et al. Prognostic significance of urokinase-type plasminogen activator and plasminogen activator inhibitor-1 in primary breast cancer. Br J Cancer 1998; 77: 932-940. http://dx.doi.org/10.1038/bjc.1998.154

[51] ITO H, YONEMURA Y, FUJITA H, TSUCHIHARA K, KAWAMURA T et al. Prognostic relevance of urokinasetype plasminogen actiator ( $\mathrm{uPA}$ ) and plasminogen activator inhibitor PAI 1 and PAI 2 in gastric cancer. Virchows Arch 1996; 427: 487-496. http://dx.doi.org/10.1007/BF00199509

[52] ANGENETE E, LANGENSKIOLD M, PALMGREN I, FALK P, ORESLAND T et al. uPA and PAI-1 in rectal cancer-relationship to radiotherapy and clinical outcome. J Surg Res 2009; 153: 46-53. http://dx.doi.org/10.1016/j.jss.2008.02.043

[53] NIELSEN HJ, CHRISTENSEN IJ, SORENSEN S, MOESGAARD F, BRUNNER N. Preoperative plasma plasminogen activator inhibitor type- 1 and serum C-reactive protein levels in patients with colorectal cancer. The RANX05 Colorectal Cancer Study Group. Ann Surg Oncol 2000; 7: 617-623.

[54] HERSZENYI L, FARINATI F, CARDIN R, ISTVAN G, MOLNAR LD et al. Tumor marker utility and prognostic relevance of cathepsin B, cathepsin L, urokinase-type plasminogen activator, plasminogen activator inhibitor type-1, CEA and CA 19-9 in colorectal cancer. BMC Cancer 2008; 10: 194. http://dx.doi.org/10.1186/1471-2407-8-194

[55] ZHANG X, SHU XO, CAI Q, RUAN Z, GAOET YT al. Functional plasminogen activator inhibitor-1 gene variants and breast cancer survival. Clin Cancer Res 2006; 12: 6037-6042. http://dx.doi.org/10.1158/1078-0432.CCR-05-2851

[56] LEI H, HEMMINKI K, JOHANSSON R, ALTIERI A, ENQUIST $\mathrm{K}$ et al. PAI-1 -675 4G/5G polymorphism as a prognostic biomarker in breast cancer. Breast Cancer Res $\mathrm{Tr}$ 2008; 109: 165-175. http://dx.doi.org/10.1007/s10549-0079635-3

[57] BLASIAK J, SMOLARZ B. Plasminogen activator inhibitor-1 (PAI-1) gene $4 \mathrm{G} / 5 \mathrm{G}$ promoter polymorphism is not associated with breast cancer. Acta Biochim Pol 2000; 47: 191-199.

[58] Li H, SHINOHARA ET, CAI Q, CHEN H, COURTNEY R et al. Plasminogen activator inhibitor-1 promoter polymorphism is not associated with the aggressiveness of disease in prostate cancer. Clin Oncol 2006; 18: 333-337. http://dx.doi. org/10.1016/j.clon.2006.02.005

[59] VOSSEN CY, HOFFMEISTER M, CHANG-CLAUDE JC, ROSENDAAL FR, BRENNER H. Clotting factor gene polymorphisms and colorectal cancer risk. J Clin Oncol 2011; 29: 1722-1727.

[60] PALMIROTTA R, FERRONI P, SAVONAROLA A, MARTINI F, CIATTI F et al. Prognostic value of pre-surgical plasma PAI1 (plasminogen activator inhibitor-1) levels in breast cancer. 
Thromb Res 2009; 124: 403-408. http://dx.doi.org/10.1016/ j.thromres.2009.02.014

[61] TEE YT, WANG PH, TSAI HT, LIN LY, LIN HT et al. Genetic polymorphism of urokinase-type plasminogen activator is interacting with plasminogen activator inhibitor-1 to raise risk of cervical neoplasia. J Surg Oncol 2012; 106: 204-208. http://dx.doi.org/10.1002/jso.23072

[62] SU CK, YEH KT, YEH CB, WANG PH, HOET ES et al. Genetic polymorphism of the plasminogen activator inhibitor-1 is associated with an increased risk of endometrial cancer. J Surg Oncol 2011; 104: 755-759. http://dx.doi.org/10.1002/ jso.22035
[63] GILABERT-ESTELLES J, RAMON LA, BRAZA-BOILS A, GILABERT J, CHIRIVELLA $M$ et al. Plasminogen activator inhibitor-1 (PAI-1) 4 G/5 G polymorphism and endometrial cancer. Influence of PAI-1 polymorphism on tissue PAI-1 antigen and mRNA expression and tumor severity. Thromb Res 2012; 130: 242-247. http://dx.doi.org/10.1016/ j.thromres.2011.10.007

[64] SMOLARZ B, BLASIAK J, KULIG A, ROMANOWICZ-MAKOWSKA H, DZIKI A et al. Plasminogen activator inhibitor 1 (PAI-1) levels and gene promoter polymorphisms in subjects with colorectal cancer. J Exp Clin Cancer Res 2001; 20: 247-252. 